\title{
THE RELATIONSHIP BETWEEN LEARNING METHODS, PARTICIPATION OF NURSE EDUCATOR, AND THE STUDENT'S CLINICAL PERFORMANCE AS PERCEIVED BY S1 NURSING STUDENTS (STAGE 1)
}

\author{
Elly Nurachmah*, Yulia**, Agus Setiawan***
}

\begin{abstract}
Abstrak:
Pengalaman di klinik memperlihatkan bahwa beberapa rumah sakitmempekerjakan perawat dari lulusan perguruan tinggi. Alasain keaadaan ini adanya persepsi dari manajemen rumah sakit menolak perawat yang baru lulus. Mereka menganggap bahwa perawat ini tidak siap untuk bekerja karena gagal menunjukkan kemampuan klinik yang diharapkan, yang mungkin disebabkan oleh beberapa faktor. Fenomena di atas menghasilkan asas teoritis yang dapat diperdebatkan karena belum ada temuan ataupun studi yang dapat menjelaskan penyebabnya. Tujuan dari penelitian ini adalah untuk mengidentifikasi hubungan antara metoda pembelajaran di kelas dan laboratorium, partisipasi pembimbing klinik, dengan kinerja klinik yang dipersepsikan oleh mahasiswa program ners yang sedang menjalani tahap profesi. Penelitian ini terdiri dari dua tahap. Disain dari penelitian tahap pertama adalah deskripsi dan analisa korelasi. Data dikumpulkan dengan menggunakan pendekatan cross sectional. Responden yang berpartisipasi sejumlah 120 orang. Metoda pengumpulan data yang digunakan adalah kuesioner terstruktur. Variabel utama yang diuraikan pada penelitian ini adalah metoda pembelajaran, partisipasi pembimbing klinik, dan kinerja klinik mahasiswa. Temuan dari penelitian ini menggambarkan penelitian tahap pertama. Temuan menunjukkan lebih dari separuh responden adalah usia produktif (73.4\%), suku Jawa (57.5\%), wanita (62.5\%), program B (55.8\%), dan memiliki ijazah sekolah menengah umurn (77.5\%). Tes kaikuadrat digunakan, dan menunjukkan hubungan yang spesifik antara jenis program, status perkawinan dengan kinerja klinik yang ditampilkan $(\mathrm{p}=0.00$, dan 0,01$)$. Tes regresi logistik digunakan untuk mengidentifikasi variabel yang paling mempengaruhi. Hasilnya menunjukkan bahwa metoda pembelajaran di kelas $(\mathrm{p}=0.03)$, jenis program $(0.00)$, status perkawinan $(0.01)$, dan partisipasi pembimbing kinik $(0.04)$ adalah variabel yang paling mempengaruhi kinerja klinik. Peneliti merekomendasikan lahan praktek untuk menyediakan lingkungan pembelajaran yang lebih kondusif dengan meningkatkan fasilitas dan sistem yang dapat digunakan oleh mahasiswa. Untuk institusi pendidikan, harus ada perbaikan yang signifikan dalam menyediakan sistem pembelajaran klinik untuk mahasiswa misalnya dengan meningkatkan kompetensi pembimbing kinik dan mengimplementasikan program preceptorship.
\end{abstract}

Kata kunci: perawat pendidik, mahasiswa perawat, penampilan klinik, metoda pembelajaran

\section{Abstrack:}

Clinical experience showed that many hospitals refused to employ nurses with higher degree. The reason behind the situation was the hospital management perception on the performance of the newly hired nurses. They perceived that these nurses were not ready to work due to failure to demonstrate clinical expectancy, which was suspected to have many causal factors. The phenomenon above created a debatable theoretical foundation since there was no study findings supported the reasons. The purpose of the study was to identify the relationship between learning methods in the class and laboratory, the participation of the clinical nurse educator in their clinical learning process, and the student's clinical performance as perceived by the students in their professional stage. The study consists of two stages. The design of this first stage study was a descriptive, correlation analysis. The data collected with a cross sectional approach. The study took place in several hospitals in Jakarta and community settings where the students of one faculty of nursing from public university were doing their clinical practice. Sample of the study were students in their final year and were self-involving in the professional first stage. The number of respondent was 120 subjects. Data collection method used in the study was structured questionnaires. Main research variables explored in the study were learning methods, participation of the clinical nurse educator; and clinical performance of the students. The findings in this study were reflecting the first stage. The findings demonstrated that more than half subjects were in the productive age (73.4\%), Javanese (57.5\%), female (62.5\%), from B program (55.8\%), and had completed their 12 years general education (77.5\%). The chi-square tests were conducted, and showed significant relationships between the type of the program, the marital status and the perceived clinical performance ( $p=0.00$, and 0.01 respectively). A logistic regression test was conducted to identify the most influencing variables. The result demonstrated that learning method in the class ( $p=0.03)$, type of the program $(0.00)$, marital status $(0.01)$, and participation of the nurse educator (0.04) were the most influencing variables to the clinical performance. Recommendations were extended to the management of field practice areas to provide more conducive learning environment by improving the facilities and the systems that could be used by the students. To education institution, there should be a significant improvement in providing a clinical teaching system for the students such as improving the competence of nurse educators, and implementing a preceptor ship program

Keywords: nurse educator, nurse students, clinical performance, learning method 


\section{BACKGROUND}

Nursing is a professional practice provided by those who are well prepared through a formal education and an adequate experience in practice. On th other hand, the professional practice determines the entire spectrum of professional education. The spectrum of professional education comprises of substance, methodology, setting, and future direction (Reilly \& Oermann, 1999).

As a profession, nursing possesses a unique body of knowledge and also skills used to serveclients. In addition, as a profession, nursing demands lifelong commitment from its members. The body of knowledge and skills that has to be owned by nurses are dynamic. These are because the clients to whom nurses provide services are not static human beings.

As a professional, nurses are expected to fulfil the patient' basic needs, to demonstrate clinical competence to the health care system, and to develop a professional community in the service setting. The education system provides them with a comprehensive learning system by utilizing many kinds of learning methods in the class, laboratory, and the clinical setting (Reilly \& Oermann, 1999). It provides also with professional nurse educators who have specific competencies to supervise and assist students in the field practice setting.

The nurse educator plays an important role in shaping the nurse students to be a good professional. She has to prepare students not only to possess the required knowledge and skills relevant to their practice, but also to have the ability to implement their theory of practice that will be in line with the expectation of other health care professionals and the community. She has to motivate students to have a willingness to attempt learning; in the class, laboratory, and clinical settings. She also has to inform students the components of behaviour they have to learn. She assists and supervises students in performing the expected behaviour, and reinforces students with fast feedback on their performance (Watts, 1990).
Many learning methods are employed to allow students engage in an intellectual process either in the class or laboratory, so then, they will gain experiences in the clinical settings in order to achieve their critical competencies. Methods used in the class include lectures, discussion, problem based learning, search literature. The purpose is to improve the students' critical thinking, capability in decision making, clinical judgement, and problem solving skills (Elliott, 1996).

The learning methods in the laboratory include demonstration, role-play, and simulation. The purpose is to allow the students' curiocity, self-confidence, and discipline grow and develop. In clinical setting, they will learn how to implement theory of actions (learning interventions) under supervision. The purpose of providing a variety of methods is to provide students with an appropriate process of introduction to the real situation (Taylor \& Care, 1999). The clinical performance they demonstrate should reflect their intellectual, technical capabilities, and professional attitudes (Orchard, 1994).

Clinical practice provides many opportunities for students to become skill-full in the implementation of theory of actions. Clinical practice is seen as more than the opportunity to put theory learned in the classroom and laboratory into practice. The clinical practice is viewed as more complex and presents many more realities than can be captured by the theory alone ( Benner, 1983 in Reilly \& Oermann, 1999).

Clinical practice is the most important part for the students to learn professionalism. It also provides students with the experience to face real client's problems. It is a dynamic comprised of cognitive, psychomotor, and affective behaviours. Therefore, every nurse educator has to conceptualise clinical practice from a wide perspective to provide nurse students with the opportunities to grow their own confidence as potential professional members. They have to show their clinical competence in order to become a good professional. Students have the right to expect that their nurse educators are competent (Orchard, 1994). 
Clinical experience in Indonesia showed many unsupportive comments on the graduates of the nursing higher education program. Many hospitals have refused to employ nurses with higher degree. The reason behind the situation was the hospital management perception on the performance of the newly graduate nurses. They have perceived that these nurses were not ready to work, incapable in doing medical intervention such as inserting intravenous catheter, urine catheter, and other clinical competences. They were perceived as an expensive staff who were incapable in making decision for the patients, making clinical judgement accurately, which lead to inability to solve the patients' health problems. They were stated to need learn more about problems in the actual situation.

On the other hand, the situation also demonstrated that not all nurse educators have paid optimal attention to the process of learning of their students. This was not only because the nurse educator had many other things to do, but it was suspected also because the insufficient competence of the nurse educator in supervising the students. In fact, nurse educators need to maintain their involvement in a high technological treatment modalities but limited resources. They need to become role models in order to assist nurse students to develop caring behaviour to prevent a loss of humanity in meeting the future clients needs. Therefore, their presence would have many meanings to the students.

In the real situation, many problems have been encountered in professional practice. The causal factors included limited number of clinical educator who had the requirements to assist and supervise students; the education prepared practitioners for serving the clients could not rely only on the scientific competencies but had to foster the skills essential for dealing with the reality. This situation created a poor quality and number of clinical role models. And also, the limited facilities produced non-conducive environment for the students to learn. In addition, the absence of the nurse educator increased the potentiality for the students to demonstrate inappropriate behaviour. They were not able to put theories they learned before into practice without supervision of their educator.

There were few studies exploring the important roles of the nurse educators in assisting and supervising students to put theories they learned through utilization of methods of learning into clinical practice. Therefore, the purpose of the study was to identify the relationship between learning methods, participation of the nurse educator in the clinical process of learning, and the student's clinical performance perceived by S1 nursing students. This report is the first part of the study.

\section{CONCEPTUAL FRAMEWORK}

Learning methods used in nursing school are important approaches for students to learn, internalise, and foster the intellectual, technical, and professional attitudes. These methods provide nurse students the competencies in anticipating the situation in the real world. The intellectual learning process is fulfilled with lectures, discussions, literature search, and problem based learning. The technical skills are attained in the laboratory and field practice areas with the exposure of the students to the real situation where they learn about nursing process as a scientific problem solving method. The technical skills include in the study was the critical competences determined for each nursing area. The area of nursing was fundamental nursing, medical-surgical nursing, critical care nursing, psychiatric nursing, maternity nursing, pediatric nursing, and community nursing. The professional attitudes are fostered through direct demonstration from the nurse educator and other professionals in the clinical setting. These will facilitate feelings of empathy, responsibility, altruism, accountability, appreciation to others, and self-controlled, which then lead to ethical based actions which will be reflected through intellectual, technical, and professional attitudes.

The participation of nurse educators in the students' intellectual, technical, and professional 
attitudes development processes is a vital requirement for the students' capacity building. Their roles and responsibilities in putting people-centered theories, health theories, and nature of practice theories into practice have become prerequisites for students in dealing with client' problems. Professional educators are accountable for assuring that the students are prepared for the society of real knowledge. Their focus is to develop a model of competency based supervision (Redman, Lenburg, \& Walker, 1999). They have to be available each time the student needs to implement the theories of action. A student clinical performance will become a product or indicator of the nurse educator' involvement. Clinical performance is identified as the list of critical competences in the nursing areas. The critical competence was measured based on the intellectual, technical, and also professional attitudes perceived by the students. The conceptual framework for this study is described in figure 1 below.

Educator and other professionals in the clinical setting. These will facilitate feelings of empathy, responsibility, altruism, accountability, appreciation to others, and self-controlled, which then lead to ethical based actions which will be reflected through intellectual, technical, and professional attitudes.

The participation of nurse educators in the students' intellectual, technical, and professional attitudes development processes is a vital requirement for the students' capacity building. Their roles and responsibilities in putting people-centered theories, health theories, and nature of practice theories into practice have become prerequisites for students in dealing with client' problems. Professional educators are accountable for assuring that the students are prepared for the society of real knowledge. Their focus is to develop a model of competency based supervision (Redman, Lenburg, \& Walker, 1999). They have to be available each time the student needs to implement the theories of action. A student clinical performance will become a product or indicator of the nurse educator' involvement. Clinical performance is identified as the list of critical competences in the nursing areas. The critical competence was measured based on the intellectual, technical, and also professional attitudes perceived by the students. The conceptual framework for this study is described in figure 1 below.

Exposure of the students to the real situation where they learn about nursing process as a scientific problem solving method. The technical skills include in the study was the critical competences determined for each nursing area. The area of nursing was fundamental nursing, medical-surgical nursing, critical care nursing, psychiatric nursing, maternity nursing, pediatric nursing, and community nursing. The professional attitudes are fostered through direct demonstration from the nurse educator and other professionals in the clinical setting. These will facilitate feelings of empathy, responsibility, altruism, accountability, appreciation to others, and self-controlled, which then lead to ethical based actions which will be reflected through intellectual, technical, and professional attitudes.

The participation of nurse educators in the students' intellectual, technical, and professional attitudes development processes is a vital requirement for the students' capacity building. Their roles and responsibilities in putting people-centered theories, health theories, and nature of practice theories into practice have become prerequisites for students in dealing with client' problems. Professional educators are accountable for assuring that the students are prepared for the society of real knowledge. Their focus is to develop a model of competency based supervision (Redman, Lenburg, \& Walker, 1999). They have to be available each time the student needs to implement the theories of action. A student clinical performance will become a product or indicator of the nurse educator' involvement. Clinical performance is identified as the list of critical competences in the nursing areas. The critical competence was measured based on the intellectual, technical, and also professional attitudes perceived by the students. The conceptual framework for this study is described in figure 1 below. 


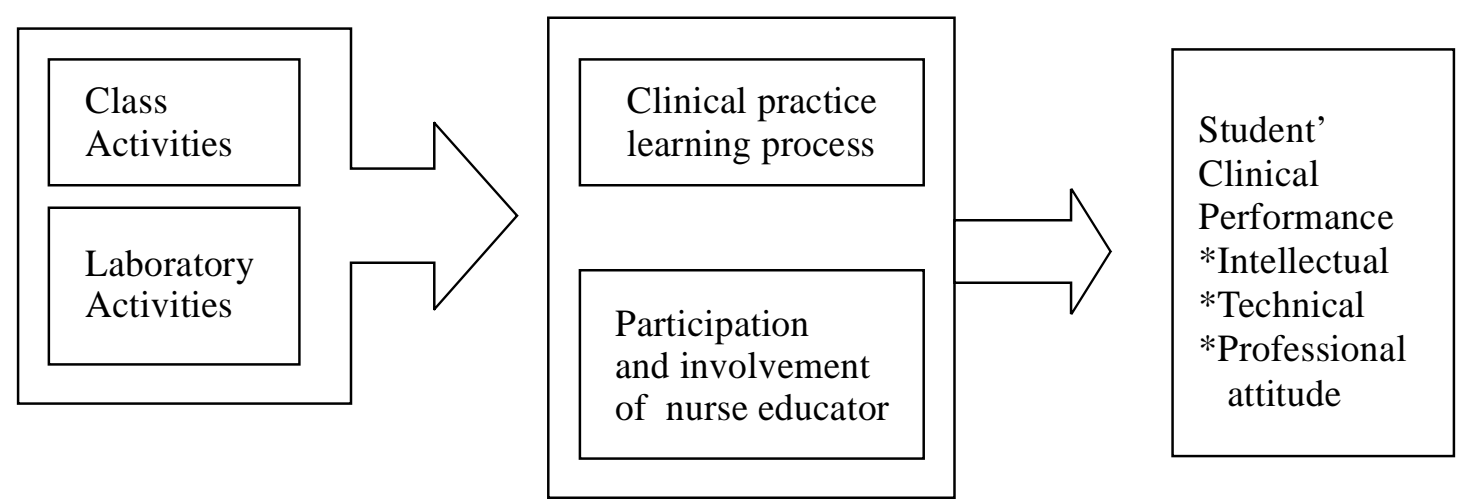

Learning methods

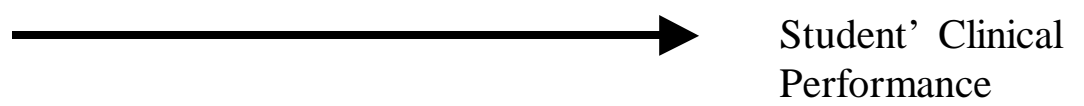

Figure 1. The conceptual framework of the study.

Based on the conceptual framework above, the framework of this study was seen in figure 2 as follow.

Learning method (class):

* Critical thinking

* Decision making

* Clinical judgement

* Problem solving

Learning methods (lab):

* Curiosity

* Self-confidence

* Discipline (to right procds)
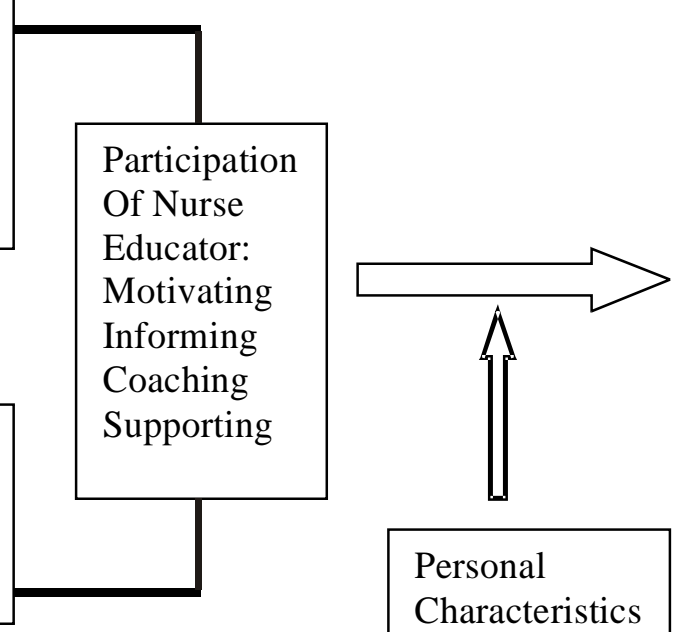

Personal

Characteristics
Perceived

clinical

performance:

Intellectual,

Technical, \&

Professional

attitudes

Figure 2. Framework of the study

\section{METHODOLOGY}

The purpose of the study was to identify the relationship between learning methods, participation of the nurse educator, and students' clinical performance. The method used in the study was a descriptive analytic, and cross sectional design. The study was conducted in field practice areas where the S1 nursing students from Faculty of Nursing- University of Indonesia practiced their theory of action into the real situation. The field practice area was several hospitals in Jakarta and community setting in Parung.
The population of the study was nurse students from Faculty of Nursing, University of Indonesia. The sample of the study was the students who were practicing their skills in the hospitals and the community settings. A number of samples were taken through a judgmental sampling. A total sample of 120 subjects were involved in the study.

Two self-assessment instruments were distributed to explore the relationship between the learning methods and their clinical performance as perceived by nurse students during their clinical placement in their first professional stage. The first in- 
strument explored the demographic data; the nurse students' perception on their learning methods used in the class, and laboratory; and the participation of their nurse educator during their clinical learning process. The second instrument assessed the clinical performance as perceived by the nurse students. The instruments measured what should be measured were shown by the validity and the reliability of 0.70 to 0.89 .

An informed consent was collected from each subject after describing the purpose, benefit, and impact of the study. The questionnaires were distributed to the subjects who were completing their first period of clinical adjustment. The subjects filled in the questionnaires and returned them at the same time.

\section{FINDINGS}

The findings consisted of demographic profiles, followed with the perception of learning methods, participation of the nurse educators, andclinical performance. The finding also showed the relationship among the variables.

The demographic profiles demonstrated that mean of age was 29.36 (SD 7.92). The minimum age was 21 and the maximum age was 54 . The number of respondents $(\mathrm{N}=110)$ who had age less than 30 years was $63 \%$ and those who had more than 30 years was $37 \%$. The majority ethnic of respondents was Java (67 \%; $\mathrm{N}=103$ ) and the remaining (37\%) was Sumatra, Karo, Sulawesi Utara, Aceh and Bali. The gender consisted in female $(62.6 \% ; \mathrm{N}=98)$, and male $(14.1 \%)$. The respondents came from generic program (A program) was $38 \%(\mathrm{~N}=108)$, and B program was $62 \%$, those who were married was 48 $\%(\mathrm{~N}=102)$, and not married 52\%. Their basic education was senior high school $(87 \%, \mathrm{~N}=107)$ and SPK (junior highplus three year nursing education was $13 \%)$.

The descriptive statistics of the variables in the study were distributed according to the subvariables of each variable. The learning methods consisted of learning methods in the class, learning method in the laboratory and the participation of the nurse educator. Each variable consisted of subvariables. The perception of the clinical performance included intellectual, technical and professional attitudes. The result was as follow.

Table 1. Learning methods

Frequency distribution of the variables.

\begin{tabular}{lccccc}
\hline & N & Min & Max & Mean & SD \\
\hline Learning methods in the class & & 2.35 & 4.73 & 3.68 & 0.43 \\
Critical thinking & 111 & 2.42 & 4.92 & 3.74 & 0.41 \\
Decision making & 109 & 2.08 & 4.67 & 3.69 & 0.45 \\
Clinical judgement & 113 & 2.08 & 4.75 & 3.58 & 0.46 \\
Problem solving & 114 & 2.25 & 4.75 & 3.73 & 0.43 \\
Learning methods in the laboratory & & 0.75 & 3.75 & 3.18 & 0.38 \\
Curiocity & 116 & 1.00 & 5.00 & 4.24 & 0.52 \\
Self Confidence & 117 & 1.00 & 5.00 & 4.26 & 0.55 \\
Discipline & 118 & 1.00 & 5.00 & 4.23 & 0.53 \\
Participation & & 2.20 & 4.47 & 3.45 & 0.51 \\
Motivating & 117 & 1.60 & 4.00 & 2.98 & 0.46 \\
Informing & 115 & 2.33 & 5.00 & 3.61 & 0.55 \\
Guiding & 117 & 1.60 & 5.00 & 3.48 & 0.63 \\
Supporting & 117 & 2.25 & 4.75 & 3.74 & 0.59 \\
Clinical performance & & 3.00 & 4.87 & 4.02 & 0.46 \\
Intellectual & 117 & 3.00 & 4.90 & 3.99 & 0.41 \\
Technical & 108 & 2.10 & 5.00 & 3.75 & 0.71 \\
Professional attitudes & 116 & 3.00 & 5.00 & 4.23 & 0.47 \\
\hline
\end{tabular}


Table 1 showed that every variable in the questionnaires was responsed vary. It could be read from the average mean of all variables. The average mean of the variables was ranged of 2.98 to 4.26 which meant from hesitance to almost absolutely agree.

The descriptive analyses from the variables were continued to explore the category of each variable. The category was divided to two, which was good and not good. The detail was described in table 2 .

Table 2 Category of each variable.

Frequency distribution of variables based on the category

$(\mathrm{N}=120)$

\begin{tabular}{cccc|cc|c} 
& F & $\%$ & Min & Max & Mean & SD \\
\hline Learning methods & & & 0.00 & 1.00 & 0.54 & 0.5 \\
Good & 51 & 42.5 & & & & \\
Not goood & 43 & 35.8 & & & & \\
Miss.data & 26 & 21.7 & & & & \\
Participation & & & 0.00 & 1.00 & 0.55 & 0.49 \\
Good & 61 & 50.8 & & & & \\
Not good & 50 & 41.7 & & & & \\
Miss.data & 9 & 7.5 & & & \multirow{2}{*}{0.48} & 0.50 \\
Clin - performance & & & 0.00 & 1.00 & & \\
Good & 49 & 40.8 & & & & \\
Not good & 54 & 45.0 & & & & \\
Miss.data & 17 & 14.2 & & & &
\end{tabular}

Table 2 showed that subjects whose responses reflected in the category of good were $42.5 \%, 50.8 \%$, and $40.8 \%$ for learning methods, participation, and clinical performance respectively. Further analyses for the relationship of variables were conducted using a chi-square test with the confidence level of $95 \%$, and alpha of 0.05 . The result can be read in table 3 .

Table 3

The distribution of the relationship between variables and subvariables

\begin{tabular}{lcccc}
\hline & N & Value & df & Significance \\
\hline Program*Learning methods & 85 & 0.64 & 1 & 0.56 \\
Program*Participation & 99 & 0.94 & 1 & 0.41 \\
Program*Clin.Performance & 92 & 19.24 & 1 & $\mathbf{0 . 0 0}$ \\
& & & & \\
Marital status*Learning methods & 84 & 0.19 & 1 & 0.82 \\
Marital status*Participation & 99 & 1.85 & 1 & 0.23 \\
Marital status*ClinPerformance & 92 & 7.25 & 1 & $\mathbf{0 . 0 1}$ \\
\hline
\end{tabular}

The chi-square tests showed that two significant relationships were identified. The relationships were between program and the student' clinical performance, and between marital status of the subjects and the clinical performance.

To determine the most influencing variable, a logistic regression were done. Three variables were identified as the most influencing variables. Table 4 showed the equation. 
Table 4 The result of logistic regression test.

The distribution of variables in the equation

\begin{tabular}{lllllcccc}
\hline & $\mathbf{B}$ & $\mathrm{SE}$ & Wald & df & Signf & Exp (B) & Low & Up \\
\hline Learning Meth. & 0.835 & 0.457 & 3.342 & 1 & 0.07 & 2.306 & 0.942 & 5.647 \\
In the class & 0.987 & 0.456 & 4.675 & 1 & $\mathbf{0 . 0 3}$ & 2.683 & 1.097 & 6.564 \\
In the lab. & 0.595 & 0.410 & 2.104 & 1 & 0.15 & 1.812 & 0.811 & 4.048 \\
& & & & & & & & \\
Program & 2.111 & 0.599 & 12.406 & 1 & $\mathbf{0 . 0 0}$ & 8.257 & 2.551 & 26.732 \\
Marital Status & -1.156 & 0.435 & 7.044 & 1 & $\mathbf{0 . 0 1}$ & 0.315 & 0.134 & 0.739 \\
Participation & 0.852 & 0.419 & 4.131 & 1 & $\mathbf{0 . 0 4}$ & 2.345 & 1.031 & 5.332 \\
\hline
\end{tabular}

Table 4 demonstrated that learning method in the class, type of the program, marital status of the subjects, and participation of the nurse educator were most influencing variables to the students' clinical performance.

\section{DISCUSSION}

The results of the study showed that the methods of learning did not have any effect to the students' clinical performance. This was not in line with Reilly \& Oermann (1999) who stress that the spectrum of professional education comprises of substance, methodology, setting, and future direction. Their statement showed that the way students learn before going to the clinical setting should be in line with what the students will find in the clinics.

The finding was not supported also by Elliot (1996) who states that class activities promote critical thinking ability that should also be facilitated in the clinical setting. This study revealed that any method they learned in the class or laboratory would not have any impact if the nurse educator did not show the conjunction between the purpose of learning in the class and laboratory with learning process in the clinics, and facilitate the opportunities to apply theory into the practice. Reilly and Oermann (1999) supported that what they need is opportunities to practice their theory in the class and laboratory to the practice setting (Reilly \& Oermann, 1999). They need opportunities to practice analysing clients situation, formulating problems, and proposing solutions (Vanetzian \& Corrigan, 1996).
Further tests demonstrated that characteristics of the subject had significant relationship with perceived students' clinical performance. The type of the program had siginificant relationship with clinical performance $(\mathrm{p}=0.00 ; \alpha .05)$; and marital status of the subjects had also significant relationship with clinical performance $(\mathrm{p}=0.01$; $\alpha .05)$. This results showed that the background of the subject influence the clinical performance. It gave a meaning that to enter the new situation they need to be reorientated again. This was because many students carry multiple responsibilities related to work and families. The finding is supported by Alverson (1999) that one goal of baccalaurate education after initial nursing preparation at diploma level is socialization to new role expectations (p.6).

Another findings in this study determined that method in the class and participation of nurse educator were the most influencing variables $(\mathrm{p}=0.03$; and $p=0.04$ respectively; $\alpha .05)$. In addition, type of program and marital status revealed the same results $(\mathrm{p}=0.00$; and $\mathrm{p}=0.01 ; \alpha .05)$. The findings concluded that those variables had significant impact to the students'clinical performance.

This result was supported by Taylor and Care (1999) that regardless the level of education and the status, the student' clinical experience was 
facilitated by their supervisor (head nurse, nurse educators, or senior staff). It meant that they have to know themself since the beginning they enter the program. They learned about nursing by participating in the practice environment for certain period. So they have to become comfortable with engaging in their activities.

Watts (1990) stated that the clinical educator has to motivate students to have a willingness to attempt learning in the class, laboratory, and clinical settings. She also has to inform students the components of behaviour to be learned. She assists and supervises students in performing the expected behaviour, and reinforces students with fast feedback on their performance (Watts, 1990). In addition, nurse educator must assess student' application of theory to clients in the clinical setting and ensure the harmless care. She also must provide adequate supervision and direction to ensure that their clinical students are able to administer safe nursing care (Orchard, 1994). Therefore, the presence of nurse educator would be a must for the students.

Galagher, Bomba, and Anderson (1999) supported that nursing students have demonstrated high level of anxiety if their clinical educators contribute inconsistent intruction. This might lead to lack of self-confidence. For this reason, nurse educators are called upon to examine the outcomes of clinical practice at the undergraduate level, considering the extensive knowledge and skills to be developed for entry level of practice in any health care setting (Oermann, 1994, p. 217).

As a summary, the results of the study had shown that subjects who had either type of the program nor the marital status need consistent supervision and assistance from their clinical educator. In addition, learning method in the class and participation of the nurse educator would become good indicators for the students to achieve their expected clinical performance.

\section{LIMITATION OF THE STUDY}

This study used cross-sectional approach that had limited ability to measure cause and effect. The instruments utilized in the study were self-developed, so the validity and reliability was applied only for the population in the study. The design of the study was not measuring the effectiveness of independent variables. Finally, the findings could not be generalized to the other population since the sampling was not randomised and the number of the sample could not maintained the power of the study.

\section{IMPLICATIONFORNURSINGPRACTICE}

However, the study has important implication to nursing education, nursing service, and nursing research. The education institution should have a good system to maintain the process of student's learning in the clinical settings where the nurse educators are available to supervise and assist students. A supervisory system should be re-designed, and the competence of the nurse educator should be improved. A policy should be made between education institution and service to ensure good collaboration.

The result of the study provided important information for the nursing management in the hospital to initiate and facilitate a condusive learning environment for students to implement the theory into practice. Re-structuring the ward management should be made to involve students in maintaining a good quality of care.

This study was the first part of the study to exploring learning methods, participation of nurse educator, and perceived clinical performance. So, this was a preliminary study. Further study should be made and focus on the effectiveness of methods of learning, participation of nurse educator on the students' clinical performance (MS).

\section{ACKNOWLEDGEMENT}

A grateful thank and appreciation are extended to the nurse students from Faculty of Nursing, University of Indonesia who had conveniently participated in the study. 


\section{REFERENCES}

Elliott, D.D. (1996). Promoting critical teaching in the classroom. Nurse educator, 21 (2), p. 49-52.

Gallagher, P., Bomba, C., \& Anderson, B. (1999). Continuity of clinical instruction: The effect on freshmean nursing students. Nurse educator, 24 (4), p. 6-7.

Oermann, M. (1994). Reforming nursing education for future practice. Nurse educator, 33 (5), p. 215-219.

Orchard, C. (1994). The nurse educator and the nursing student: A review of the issue of clinical evaluation procedures. Nurse educator, 33 (6), p. $245-251$.
Redman, R.W., Lenburg, C. B., \& Walker, P. H. (1999). Competency assessment: Methods for development and implementation in nursing education. Online Journal of Issues in Nursing, September.

Reilly, D. E., \& Oermann, M. H. (1999). Clinical teaching in nursing education. Second edition. Boston: Jones and Barttlett Publishers.

Taylor, K. L. , \& Care, W. D. (1999). Nursing education as cognitive apprenticeship. A framework for clinical education. Nurse educator, 24 (4), p. 31- 36.

Vanetzian, E., \& Corrigan, B. (1996). "Prep" for class and class activitiy. Key to critical thinking. Nurse educator, 21 (2), p. 45-48.

Watts, N. T. (1990). Handbook of clinical teaching. Edinburgh: Churchill and Livingstone. 